\title{
IMPLEMENTASI PROGRAM PERBIKAN GIZI MASYARAKAT KATEGORI BALITA BERSTATUS GIZI KURANG DI KELURAHAN SUNGAI MALANG KABUPATEN HULU SUNGAI UTARA
}

\author{
Reno Affrian \\ Sekolah Tinggi Ilmu Administrasi (STIA) Amuntai \\ Email: renoaffrian@yahoo.com
}

\begin{abstract}
Based on Basic Health Research (RKD) and Toddler Operations in North Hulu Sungai Utara, nutritional problems are less increasing in the last three years, 2015 less than 17.32\% malnutrition, 2016 less than $20.54 \%$ and nutrition prevalence less by 24\%. Less nutritional problems in Hulu Sungai Utara Regency are included in the categorization of serious public health problems due to nutritional prevalence above 20\%. mapping of the poor urban village region donated the most under-five children under five, namely 537 children under five. Based on the results of the research that the implementation of nutrition improvement program for under-fives under-nutrition category in urang sub-district in the northern river upstream district has not run well enough, it is known from: 1. Environmental aspect in the form of community economic environment and family care pattern, 2. Target group, some program implementers are not yet fully aware of the targets set by the government nationally, 3. Program activities, activities carried out only as routine activities ie immunization activities and postal services yando, 4.Pengelolaan Management and Pengawasa, not fully run well it diliat still lack inter-sectoral coordination, factors affecting nutrition improvement program for under-fives under-fives category in poor urban village influenced by several factors 1. Policy Size and Objectives 2. Resources, 3. Characteristics of implementing agents, 4. Attitudes / implementers, 5. Intercommunications organization and activities of the implementer, 6. Economic, social and political environment.
\end{abstract}

Keywords: implementation, program, toddler nutrition

\section{PENDAHULUAN}

Peraturan Menteri Kesehatan Republik Indonsesia Nomor 23 Tahun 2004 Tentang Upaya Perbaikan Gizi Pasal 7 memerintahkan pemerintah daerah kabupaten/kota bertugas dan bertanggung jawab dalam penyelenggaraan dan fasilitasi gizi, penanggulangan gizi buruk, perbaikan gizi keluarga dan masyarakat, memenuhi kecukupan dan perbaikan perbaikan gizi masyarakat terutama pada keluarga miskin dan rawan gizi serta dalam situasi darurat, meningkatkan pengetahuan dan kesadaran masyarakat akan pentingnya gizi dan pengaruhnya terhadap peningkatan status gizi; menyelenggarakan pelayanan upaya perbaikan gizi, melaksanakan faasilitasi, perizinan, koordinasi, monitoring dan evaluasi pelaksanaan urusan wajib upaya perbaikan gizi wilayah kabupaten/ kota,

Kabupaten Hulu Sungai Utara (HSU) merupakan salah satu kabupaten yang bertugas dan bertanggung jawab menjalankan Peraturan Menteri Kesehatan Republik Indonsesia Nomor 23 Tahun 2004 Tentang Upaya Perbaikan Gizi, Berdasarkan Riset Kesehatan Dasar (RKD) dan Operasi Timbang Balita di Kabupaten Hulu Sungai Utara permasalahan gizi kurang semakin meningkat tiga tahun terakhir, tahun 2015 prevalensi gizi kurang 17,32 \%, tahun 2016 prevalensi gizi kurang $20,54 \%$ dan pada tahun 2017 pvalensi gizi kurang sebesar $24 \%$. Permasalahan gizi kurang di Kabupaten Hulu Sungai Utara termasuk dalam kategori masalah kesehatan masyarakat berat karena prevalensi 
gizi diatas 20\%. Dalam penelitian ini peneliti mengambil lokus penelitian pada Kelurahan Sungai Malang dilihat dari pemetaan wilayah Kelurahan Sungai Malang paling banyak menyumbangkan balita berstatus gizi kurang yakni 537 orang balita, sedangkan Kecamatan Amuntai Selatan yang lebih luas cakupannya hanya 454 balita yang berstatus gizi kurang.

\section{METODE PENELITIAN}

Jenis Penelitian yang digunakan dalam penelitian ini adalah jenis Kualitatif. diharapkan dengan jenis ini akan ditemukan makna yang tersembunyi dibalik obyek maupun subjek yang akan diteliti. Jenis Penelitian Kualitatif sebagai suatu konsep keseluruhan berupaya untuk mengungkapkan rahasia sesuatu, dilakukan dengan menghimpun informasi dalam keadaan sewajarnya.

Sumber data adalah tempat atau asal data yang diperoleh dan dipergunakan. Sumber data dalam penelitian ini adalah 1). Data primer, data Primer merupakan data asli yang memuat informasi atau data yang langsung diperoleh dari Informan, Pemilihan informan dilakukan dengan cara purposive (bertujuan) yakni orang yang dianggap mengetahui permasalah tentang implementasi program perbaikan gizi masyarakat kategori balita berstatus gizi kurang di Kelurahan Sungai Malang Kabupaten Hulu Sungai Utara 2). Data Sekunder adalah data yang tidak langsung memberikan data kepada peneliti, misalnya penelitian harus melalui orang lain atau mencari melalui dokumen. Data ini diperoleh dengan menggunakan studi literatur yang dilakukan terhadap banyak buku dan diperoleh berdasarkan catatan-catatan yang berhubungan dengan penelitian. Instrumen utama dalam penelitian ini adalah peneliti itu sendiri, dimana peneliti merupakan alat pencari informasi, menilai keadaan/tindakan dan mengambil keputusan dalam usaha pengumpulan data. Sebagai alat bantu dalam pengumpulan data, digunakan pula buku catatan, kamera untuk merekam gambar-gambar selama proses penelitian berlangsung, handphone perekam untuk merekam kegiatan selama proses berlangsung.
Teknik pengumpulan data, Pengumpulan data Primer dilakukan dengan dua cara, yaitu Wawancara mendalam (depth interview) dan observasi lapangan. Wawancara mendalam, untuk itu dilakukan dengan metode snow bowling, berangkat dari informan yang sangat terbatas informasinya ke informan yang lebih luas dan mendalam informasinya yang mengetahui tentang permasalahan yang akan diteliti. Digunakan pula data sekunder yang pengumpulan dilakukan melalui kajian pustaka, sumber tertulis seperti buku, artikel, dokumen, dan lain-lain yang masih ada relevansinya dengan bidang kaji penelitian.

Analisis data dalam penelitian Kualitatif bersifat induktif dimana data yang diperoleh akan dianalisis dan dikembangkan menjadi sebuah asumsi dasar penelitian, kemudian datadata lain terus dikumpulkan dan ditarik kesimpulan. Analisis data dalam penelitian ini menggunakan model Miles and Huberman dalam Sugiyono (2014:91) Data-data yang dikumpulkan dianalisis melalui beberapa tahapan yaitu data reduction, data display dan conclusion drawing/verification sehingga dapat diambil suatu kesimpulan.

\section{HASIL DAN PEMBAHASAN}

\section{A. Implementasi Program Perbaikan Gizi Masyarakat Kategori Balita Berstatus Gizi Kurang diKelurahan Sungai Malang}

Syukur (1988:398) menjelaskan bahwa pengertian dan unsur unsur pokok dalam proses implementasi sebagai berikut :

1. Proses implementasi program ialah rangkaian kegiatan tindak lanjut yang terdiri atas pengambilan keputusan, langkah langkah yang strategis maupun operasional yang ditempuh guna mewujudkan suatu program atau kebijaksanaan menjadi kenyataan, guna mencapai sasaran yang ditetapkan semula.

2. Proses implementasi dalam kenyataanya yang sesunguhnya dapat berhasil, kurang berhasil ataupun gagal sama sekali ditinjau dari hasil yang dicapai "outcomes" serta unsur yang 
pengaruhnya dapat bersifat mendukung atau menghambat sasaran program.

3. Dalam proses implementasi sekurangkurangnya terdapat empat unsur yang penting dan mutlak yaitu :

a. Implementasi program atau kebijaksanaan tidak mungkin dilaksanakan dalam ruang hampa. Oleh karena itu faktor lingkungan akan mempengaruhi proses implementasi program pada umumnya.

b. Target group yaitu kelompok yang menjadi sasaran dan diharapkan akan menerima manfaat program tersebut.

c. Adanya program yang dilaksanakan.

d. Unsur pelaksanaan atau implementer, baik organisasi atau perorangan yang bertanggung jawab dalam pengelolaan, pelaksanaan dan pengawasan implementasi tersebut.

Dinas Kesehatan Kabupaten Hulu Sungai Utara merupakan lembaga yang bertanggung jawab menjalankan program perbaikan gizi masyarakat, dalam rangka menjalankan tugas perbaikan gizi masyarakat Dinas Kesehatan dibantu oleh Puskesmas, puskesmas sungai malang salah satu puskesmas pembantu program perbaikan gizi masyarakat, secara umum tugas dan fungsi puskesmas mempersiapkan, memelihara dan mempertahankan orang agar mempunyai status gizi baik, Pelayanan imunisasi dan posyandu merupakan kegiatan rutin yang dilaksanakan oleh puskesmas sungai malang, Pemenuhan gizi balita sangat penting untuk diupayakan, pemenuhan nutrisi yang lengkap dan seimbang bagi balita akan mempengaruhi perkembangan otak, aktivitas fisik dan kongnitifnya.

Hasil penelitian yang penulis lakukan menunjukan bahwa : 1). Aspek Lingkungan, a) Lingkungan ekonomi, kondisi ekonomi masyarakat memiliki dampak yang kuat terhadap keberhasilan program perbaikan gizi masyarakat khususnya upaya perbaikan gizi balita, puskesmas sungai malang membina 21 desa, dari 21 desa binaan pada umumnya mata pencarian masyarakat bertani dan peternak, dari kasus yang ditemukan 537 balita berstatus gizi kurang di Kelurahan Sungai Malang rata-rata keluarga yang mengalami masalah ekonomi, kondisi ekonomi keluarga sangat berpengaruh terhadap daya beli atau konsumsi gizi yang diberikan orang tua terhadap anaknya, sehingga Program perbaikan gizi yang dirasakan sangat baik tetapi para sasaran kebijakan masih mengalami kondisi ekonomi yang masih kurang maka akan menghambat keberhasilan suatu kebijakan maupu program, b) Lingkungan Keluarga, Lingkungan keluarga berupa pola asuh atau interaksi anak dengan orangtua, berdasarkan kasus dan wawancara peneliti masih banyak ditemukan orang tua di Kelurahan Sungai Malang yang pola asuhnya terhadap anak tidak memperhatikan keseimbangan gizi, seperti pola pemberian asi terhadap anak minimal 6 bulan, masih banyak keluarga yang kurang menyadari bahwa gizi anak merupakan investasi masa depan. 2). Target Group, Rencana Aksi Nasional Pangan dan Gizi Pada tahun 2015 2019 yang menyatakan bahwa ukuran keberhasilan Program Gizi ditetapkan dengan Standar Minimum 20\% Secara Nasional. Berdasarkan hasil wawancara yang peneliti lakukan sebagian besar Petugas Dinas Kesehatan dan Petugas Puskesmas Sungai Malang yang menjalankan program perbaikan gizi masyarakat tak sepenuhnya memahami ukuran atau standar keberhasilan program gizi secara nasional yang ditetapkan oleh Pemerintah. Penetapan perbaikan gizi Masyarakat yang dicanangkan Pemerintah sebesar 20\% Secara Nasional akan berhasil apabila pelaksana kebijakan melakukan kegiatan-kegiatan inovasi dibidang kesehatan gizi, Ketika ukuran kebijakan atau tujuan kebijakan terlalu ideal untuk dilaksanakan dilevel pelaksana kebijakan dan warga, maka agak sulit memang merealisasikan. 3). progam/kegiatan yang dilaksanakan, Salah satu kegiatan yang dilakukan Dinas Kesehatan Kabupaten Hulu Sungai Utara dan Puskesmas Sungai Malang dalam rangka menjaga perbaikan gizi balita berupa pelayanan imunisasi dan posyandu, kegiatan tersebut merupakan kegiatan rutin yang dilaksanakan oleh 
Puskesmas Sungai Malang, Selain melakukan kegiatan rutin pegawai Dinas Kesehatan dan Puskesmas selalu melakukan pemantauan dan pembinaan terhadap keluarga agar yang anaknya berstatus gizi kurang, pemantauan tersebut berupa aktivitas melakukan kunjungan kepada keluarga yang anaknya diduga mengalami permasalahan gizi, dalam rangka meningkatkan gizi masyarakat di kelurahan sungai malang Dinas Kesehatan, Pusekesmas Sungai Malang dibantu oleh Dinas KKKBN dengan programnya Bina Keluarga Harapan yang menempatkan 3 orang kader pada setiap desa di Hulu Sungai Utara. 4). Pengelolaan dan Pengawasan, Pengelolaan dan Pengawasan program perbaikan gizi masyarakat kategori balita berstatus gizi kurang di Kelurahan Sungai Malang belum Sepenuhnya optimal, Setelah ditetapkannya program perbaikan gizi masyarakat pada tahun 2014 perhatian dan pengawasan yang dilakukan oleh pemerintah daerah belum sepenuhnya berjalan dengan baik hal tersebut diliat masih kurangnya koordinasi antar lintas sektor dalam menjalankan program gizi masyarakat khususnya peningkatan gizi pada balita. Walaupun kegiatan-kegiatan rutin telah dilakukan akan tetapi dalam hal pengawasan belum sepenuhnya optimal.

\section{B. Faktor yang mempengaruhi Program Perbikan Gizi Masyarakat Kategori Balita Berstatus Gizi Kurang di Kelurahan Sungai Malang}

\section{Ukuran dan Tujuan Kebijakan}

\section{a. Ukuran}

Kinerja implementasi kebijakan dapat diukur tingkat keberhasilan jika ukuran dan tujuan dari kebijakan memang realitis dengan sosio-kultur yang mengada dilevel pelaksana kebijakan. Ketika ukuran kebijakan atau tujuan kebijakan terlalu ideal (bahkan terlalu utopis) untuk dilaksanakan dilevel warga, maka agak sulit memang merealisasikan kebijakan publik hingga titik yang dapat dikatakan berhasil.

Pelaksanaan kebijakan program gizi masyarakat di Kelurahan Sungai Malang kategori balita berstatus gizi kurang dapat diketahui bahwa pelaksana kegiatan program gizi dan masyarakat belum sepenuhnya memahami ukuran atau standar keberhasilan program gizi secara nasional yang ditetapkan oleh Pemerintah. Penetapan perbaikan gizi Masyarakat yang dicanangkan Pemerintah sebesar 20\% Secara Nasional ternyata masih belum sepenuhnya diketahui oleh pelaksana kebijakan maupun sasaran kebijakan.

b. Tujuan Kebijakan

Setiap Kebijakan yang dikeluarkan atau ditetapkan oleh pemerintah pasti memiliki tujuan, tujuan pembuatan kebijakan publik pada dasarnya untuk mewujudkan ketertiban dalam masyarakat, melindungi hak-hak masyarakat, mewujudkan ketentraman dan kedamaian dalam masyarakat dan mewujudkan kesejahteraan masyarakat.

Pelaksanaan kebijakan program gizi masyarakat di Kelurahan Sungai Malang kategori balita berstatus gizi kurang dapat diketahui bahwa sebagian besar pelaksana kebijakan maupun sasaran kebijakan mengetahui bahwa tujuan program gizi kurang untuk meningkatkan kesehatan gizi masyakarat.

\section{Sumber daya}

Keberhasilan proses implementasi kebijakan sangat tergantung dari kemampuan memanfaatkan sumberdaya yang tersedia. Manusia merupakan sumberdaya yang terpenting dalam menentukan suatu keberhasilan proses implementasi. Tahap-tahap tertentu dari keseluruhan proses implementasi menuntut adanya sumberdaya manusia yang berkualitas sesuai dengan pekerjaan yang diisyaratkan oleh kebijakan yang telah ditetapkan secara politik.

a. Sumber Daya Manusia

Efektivitas pelaksanaan kebijakan sangat tergantung kepada sumber daya manusia (aparatur) yang bertanggung jawab melaksanakan kebijakan. Staf yang relatif cukup jumlahnya dan mempunyai keahlian dan keterampilan untuk melaksanakan tugas akan mempengaruhi keberhasilan suatu program kebijakan. 
Pelaksanaan kebijakan program gizi masyarakat di Kelurahan Sungai Malang kategori balita berstatus gizi kurang dapat diketahui bahwa sumber daya manusia (staf) untuk menjalankan program gizi belum sepenuhnya mencukupi, Pelaksana tugas pembantu pada puskesmas sungai malang satu orang membina tiga desa dari dua puluh satu desa yang ada di Kelurahan Sungai Malang, yang berarti dapat disimpulkan bahwa jumlah staf belum memenuhi kebutuhan untuk menjalankan program gizi kurang.

b. Sumber daya Finansial

Sumberdaya finansial menentukan proses berjalan tidaknya kebijakan, ketika sumberdaya manusia yang kompeten dan kapabel telah tersedia sedangkan kucuran dan melalui anggaran tidak tersedia, maka memang menjadi persoalan pelik untuk merealisasikan apa yang hendak dituju oleh tujuan kebijakan publik

Pelaksanaan program gizi masyarakat di Kelurahan Sungai Malang kategori balita berstatus gizi kurang dapat diketahui bahwa sebagian besar pelaksana kegiatan program perbaikan gizi kurang menyatakan dana belum sepenuhnya mencukupi untuk melakukan kegiatankegiatan inovasi berupa sosialisasi, penyuluhan dan kampanye tentang perbaikan gizi masyarakat.

c. Sarana Prasarana

Sarana dan prasarana sangat dibutuhkan dalam pencapaian tujuan, sarana prasarana yang lengkap akan mempermudah pelaksana program perbaikan gizi masyarakat untuk menjalakan segala kegiatan. Pelaksanaan program gizi masyarakat kelurahan sungai malang kategori balita berstatus gizi kurang dapat diketahui sarana prasarana sudah mencukupi untuk menjalankan kegiatan program kesehatan gizi masyarakat, sehingga segala kegaitan akan dipermudah apabila tersediannya sarana prasarana yang lengkap.

\section{Karakteristik Agen Pelaksana}

Pusat perhatian pada agen pelaksana meliputi organisasi formal dan organisasi informal yang akan terlibat pengimplemntasian kebijakan publik. Hal ini sangat penting karena kinerja implementasi kebijakan (Publik) akan sangat banyak dipengaruhi oleh ciri-ciri yang tepat serta cocok dengan para agen pelaksananya.

Pelaksanaan kebijakan program gizi masyarakat di Kelurahan Sungai Malang kategori balita berstatus gizi kurang dapat diketahui bahwa agen Pelaksana Perbaikan Gizi masyarakat adalah Dinas Kesehatan, Puskesmas, Dinas BKKBN dan Dinas Pertahanan Pangan. Hal tersebut sesuai dengan karakteristik agen pelaksana.

\section{Sikap/Kecendrungan (Disposition) para Pelaksana.}

Sikap penerimaan atau pelaksanaan dari (agen) pelaksana akan sangat banyak mempengaruhi keberhasilan atau tidaknya kinerja implementasi kebijakan publik. Hal ini sangat mungkin terjadi oleh karena kebijakan yang dilaksanakan bukanlah hasil formulasi warga setempat yang mengenal betul persoalan dan permasalahan yang mereka rasakan. Pelaksanaan program gizi masyarakat Sungai Malang kategori balita berstatus gizi kurang dapat diketahui bahwa sebagian besar pelaksana kebijakan maupun sasaran kebijakan (masyarakat) menyambut baik program perbaikan gizi kurang, mereka mengetahui bahwa tujuan program gizi kurang untuk meningkatakan kesehatan gizi masyakarat.

\section{Komunikasi Antarorganisasi dan Aktivitas Pelaksana}

Koordinasi merupakan mekanisme yang ampuh dalam implementasi kebijakan publik. Semakin baik koordinasi komunikasi diantara pihak-pihak yang terlibat dalam suatu proses implementasi, maka asumsi kesalahan-kesalahan akan sangat kecil untuk terjadi, dan begitu pula sebaliknya.

a. Koordinasi Antarorganiasi

Implementasi Program Perbikan

Gizi Masyarakat Kategori Balita Berstatus

Gizi Kurang di Kelurahan Sungai Malang 
koordinasi antar organisasi belum sepenuhnya berjalan dengan baik, baik koordinasi pengenai perencanaan, pengelolaan, maupun peksanaannya.

b. Aktivitas Pelaksana

Implementasi Program Perbikan Gizi Masyarakat Kategori Balita Berstatus Gizi Kurang di Kelurahan Sungai Malang diketahui bahwa sebagian aktivitas pelaksana perbaikan gizi kurang hanya dilakukan pada kegiatan yang bersifat rutin seperti pelayanan posyandu dan imunisasi.

\section{Lingkungan Ekonomi,Sosial, dan Politik}

Hal terakhir yang perlu juga diperhatikan guna menilai kinerja implementasi publik dalam persektif yang ditawarkan oleh Van Metter dan Van Horn adalah, sejauhmana lingkungan eksternal turut mendorong keberhasilan kebijkan publik yang telah ditetapkan. Lingkungan sosial, ekonomi, dan politik yang tidak kondusif dapat menjadi biang keladi dari kegagalan kinerja implementasi kebijakan. Karena itu, upaya untuk mengimplementasikan kebijakan harus pula memperhatikan kekondusifan kondisi lingkungan eksternal.

a. Lingkungan Ekonomi

Linkungan ekonomi adalah kondisi ekonomi diwilayah sekitar, kondisi ekonomi memiliki dampak yang kuat terhadap perbaikan gizi masyarakat. Program perbaikan gizi yang dirasakan sangat baik tetapi para sasaran kebijakan masih mengalami kondisi ekonomi yang kurang maka akan menghambat keberhasilan suatu kebijakan maupun program.

Implementasi Program Perbaikan Gizi Masyarakat di Kelurahan Sungai Malang Kategori Balita Berstatus Gizi Kurang diketahui bahwa lingkungan ekonomi keluarga yang berstatus gizi kurang di sebagian besar berada pada garis ekonomi ke bawah. Hal ini sangat berpengaruh terhadap program perbaikan gizi masyarakat, apabila masyarakat sejahtera maka dimungkinkan asupan gizi akan seimbang, sehingga permasalahan gizi kurang dapat diatasi. b. Lingkungan Sosial

Lingkungan sosial juga disebut dengan konteks sosiokultur, kebiasaan masyarat sangat mempengaruhi keberhasilan suatu program perbaikan gizi masyarakat.

Implementasi Program Perbikan Gizi Masyarakat di Kelurahan Sungai Malang untuk kategori balita berstatus gizi kurang yang lingkungan sosial masyarakat sangat berpengaruh terhadap program perbaikan gizi masyarakat dan kebiasaan masyarakat dalam pola asuh yang diberikan kepada anak akan sangat mempengaruhi terhadap program perbaikan gizi masyarakat.

c. Lingkungan Politik

Lingkungan politik adalah hukum, instansi pemerintah dan kelompok penekan yang mempengaruhi dan membatasi organisasi dan individu dalam menjalankan program perbaikan gizi masyarakat.

Implementasi Program Perbaikan Gizi Masyarakat di Kelurahan Sungai Malang Kategori Balita Berstatus Gizi Kurang, perhatian dari instansi yang lebih tinggi hanya dilakukan pada saat acara kegiatan yang dilakukan oleh Dinas Kesehatan, akan tetapi acara rutinitas perhatian terhadap perbaikan gizi masih belum maksimal dilaksanakan.

\section{KESIMPULAN}

Berdasarkan hasil penelitian yang telah dilakukan dapat disimpulkan bahwa :

1. Implementasi program perbaikan gizi masyarakat kategori balita berstatus gizi kurang di kelurahan sungai malang kabupaten hulu sungai utara belum berjalan cukup baik, hal tersebut diketahui dari: 1). Aspek Lingkungan berupa lingkungan ekonomi masyarakat dan pola asuh keluarga, 2). Target group, beberapa pelaksana program belum sepenuhnya mengetahui target yang ditetapkan oleh pemerintah secara nasional, 3). Program kegiatan, kegiatan yang dilakukan hanya sebat kegiatan rutin yaitu kegiatan imunisasi dan 
pelayanan posyandu, 4). Pengelolaan dan Pengawasan, belum sepenuhnya berjalan dengan baik hal tersebut diliat masih kurangnya koordinasi antar lintas sektor.

2. Faktor-faktor yang mempengaruhi program perbaikan gizi masyarakat kategori balita berstatus gizi kurang di Kelurahan Sungai Malang dipengaruhi oleh : 1). Ukuran dan Tujuan Kebijakan, 2). Sumber daya, 3). Karakteristik agen pelaksana, 4). Sikap/ Kecenderungan para pelaksana, 5). Komunikasi Antarorganisasi dan aktivitas pelaksana, 6). Lingkungan ekonomi, sosial dan politik.

\section{SARAN}

Berdasarkan kesimpulan penelitian, maka dapat diberikan saran sebagai berikut :

1. Instansi yang menjalankan program Perbaikan gizi mayarakat khususnya untuk kategori balita perlu melakukan kampanye, penyuluhan, Sosialisasi yang terprogram, agar meningkatkan pengetahuan masyarakat tentang pentingnya asupan gizi yang seimbang bagi balita.

2. Perlu meningkatkan koordinasi antar lembaga dengan cara membuat jadwal pertemuan yang tersusun, melakukan perencanaan dan evaluasi terhadap proses perbaikan gizi masyarakat, hingga permasalahan gizi masyarakat khususnya kategori gizi kurang dapat diminimalisir keberadaannya.

\section{REFERENSI}

Abdul Wahab. 2008, Pengantar Analisis Kebijakan Publik. Hak Terbit Pada UMM Press.

Agustino, Leo. 2008. Dasar Dasar Kebijakan Publik. Bandung, Alfabeta.

Ali, Faried, et al. 2012. Studi Analisis Kebijakan. Bandung, PT Refika Aditama.
Bugin, Burhan. 2007. Penelitian Kualitatif, Komunikasi, Ekonomi, Kebijakan Publik dan Ilmu Sosial lainnya. Jakarta, Prenada Media Group.

Dunn,William N. 2003. Pengantar Analisis Kebijakan Publik. Yogyakarta, Gadjah Mada University Press

Fischer, Frank, et al. 2015. Handbook Analisis Kebijakan Publik, Teori, Politik dan Metode. Bandung, Nusa Media.

Keban.T Yeremes. 2004. Enam Dimensi Strategis Administrasi Publik, Konsep, Teori dan Isu. Yogyakarta, Gama Media.

Subarsono, AG. 2011. Analisis Kebijakan Publik Konsep, Teori dan Aplikasi. Yogyakarta, Pustaka Belajar.

Suharno, Edi. 2008. Analisis Kebijakan Publik. Bandung, Alfabeta.

Sogiyono. 2013. Metode Penelitian Kuantitatif Kualitatif Dan $R \& D$. Cetakan ke Tiga Belas. Bandung, Alfabeta.

http://ajago.blogspot.com/2007/12/gizikesehatan-masyarakat.html diakses: (Mei/2018)

http://kuliah.fkuii.org/index.php?option=com_p hocadownload \&view=category \&downloa $\mathrm{d}=874$ : gizi\%20masyarakatnew\&id=79:ke sehatan-masyarakat-4-4\&Itemid $=10746$ diakses (mei/2018).

http://eprints.uny.ac.id/7718/3/BAB\%202\%20$\% 2008603141021 . p d f$ diakses : (Mei/2018).

http://erepo.unud.ac.id/9354/3/066d476b0be30c 1511bef1b75b8467d8.pdf di akses (mei/2018). 